\title{
ANALISIS KETIDAKLENGKAPAN DOKUMEN REKAM MEDIS MENURUT STANDAR AKREDITASI RUMAH SAKIT MKI 19.1 VERSI KARS 2012 DI RUMAH SAKIT UMUM IMELDA PEKERJA INDONESIA (RSU IPI) MEDAN TAHUN 2018
}

\author{
${ }^{1}$ Esraida; ${ }^{2}$ Bintang Napitupulu \\ 1. Dosen APIKES Imelda, Jalan Bilal Nomor 52 Medan; ${ }^{2 .}$ Alumni APIKES Imelda \\ E-mail: 1 esraida.borjun@gmail.com
}

\begin{abstract}
ABSTRAK
Rumah sakit adalah institusi pelayanan kesehatan yang menyelenggarakan pelayanan kesehatan perorangan secara paripurna yang menyediakan pelayanan rawat inap,jalan dan gawat darurat. Salah satu meningkatkan mutu pelayanan dirumah sakit bisa dilihat dari kelengkapan pengisian berkas rekam medis. Tujuan dari penelitian ini adalah untuk menganalisis ketidaklengkapan dokumen rekam medis menurut standar akreditasi KARS versi 2012 pada MKI 19.1 di RSU Imelda Pekerja Indonesia Medan. Penelitian ini dilakukan pada bulan Juni 2018 dengan menggunakan teknik metode random samplingdimana populasi dipilih secara acak sebagai sampel. Jumlah populasi dalam penelitian ini adalah 440 berkas rekam medis pasien pulang, dan sampel yang digunakan dalam penelitian ini 81 berkas rekam medis pasien pulang dengan kelengkapan 66,67\% pada fomulir dokumen pemeriksaan dan fomulir ketidaklengkapan $69,14 \%$ pada identifikasi pasien.Kesimpulan dari penelitian ini adalah ketidaklengkapan dokumen rekam medis pasien pulang yang tidak memenuhi standar MKI 19.1 terdapat pada fomulir mengidentifikasi pasien dan saran dalam penelitian ini agar petugas lebih meningkatkan evaluasi pada bagian monitoring dan assembling untuk melengkapi ketidaklengkapan dokumen rekam medis pada pasien pulangMeningkatkan evaluasi pada bagian assembling untuk melengkapi ketidaklengkapan dokumen rekam medis pada pasien pulang. Memberi sanksi apabila petugas belum lengkap mengisi dokumen rekam medis pasien pulang. Memberi Reward kepada petugas yang sudah melengkapi pengisian dokumen rekam medis dengan tepat waktu.
\end{abstract}

Kata Kunci ～：Kelengkapan DRM, MKI 19.1

\section{PENDAHULUAN}

Rumah Sakit adalah institusi pelayanan kesehatan yang menyelenggarakan pelayanan kesehatan perorangan secara paripurna yang menyediakan pelayanan rawat inap, rawat jalan dan gawat darurat (PMK,No 56 Tahun 2014). Rumah sakit adalah bagian intergal dari suatu organisasi sosial dan kesehatan dengan fungsi menyediakan pelayanan paripurna (komprehsip), penyembuhan penyakit (preventif) kepada masyarakat. Setiap rumah sakit berkewajiban di upayakan menyelenggarakan rekam medis dengan baik dan benar sesuai dengan standar yang bertahap di upayakan mencapai standart internasional (UU RI 44 Tahun 2009).

Rekam medis adalah berkas berisi catatan dan dokumen pengbatan tindkan medis lain pada sarana pelayanan kesehatan untuk rawat jalan,rawat inap,maupun gawat darurat baik di kelola pemerintah maupun swasta, adapun tujuan dibuatnta rekam medis untuk mebunjang tercapainya tertib administrasi dalam rangka peningkatan mutu pelayanan kesehatan di rumah sakit (Permenkes 269/Menkes/PER/2008).Untuk mengkur mutu pelayanan dirumah sakit harus di adakannya akreditasi. 
Akreditasi adalah pengakuan terhadap mutu pelayanan rumah sakit setelah dilakukan penilaian bahwa rumah sakit telah memenuhi standar akreditasi. Standar akreditasi adalah pedoman yang berisi tingkat pencapaian yang harus dipenuhi oleh rumah sakit dalam meningkatkan mutu pelayanan dan keselamatan pasien (PMK, No 34 Tahun 2017).

Komisi Akerditasi Rumah Sakit (KARS,2012) terdapat beberapa standar yang berkaitan dengan isi rekam medis, yaitu pada kelompok standar manajemen rumah sakit. Di dalam kelompok Manajemen Rumah Sakit terdiri dari enam (6) bab mengenai rekam medis dan pada Manajemen Komunikasi dan Informasi (MKI) 19.1 berisi tentang rekam medis memuat informasi yang memadai untuk mengidentifkasi pasien, mendukung diagnosa, justifikasi pengobatan dokumen pelayanan diantara tenaga penyedia pelayanan kesehatan.

Data yang diperoleh di RSUP H Adam Malik pada bulan April berdasarkan observasi di bagian rekam medis tentang akreditasi rumah sakit bahwasannya RSUP H Adam Malik masih menggunakan standar akreditasi KARS (Komisi Akreditasi Rumah Sakit) dimana dalam analisa dokumen rekam medis terdapat 26 form rekam medis yang umum dan 33 fomulir rekam medis khusus. Pegawai di bagian analisa memeriksa semua formulir dokumen rekam medis sesuai dengan MKI 19.1 yang berisi tentang rekam medis memuat informasi yang memadai untuk mengidentifikasi pasien, mendukung diagnosa, justifikasi pengobatan dokumen pemerikasaan dan hasil pengobatan serta meningkatkan kesinambungan pelayanan diantara tenaga penyedia pelayanan kesehatan.

Berdasarkan observasi awal yang dilakukan melalui wawancara pada salah satu pegawai rekam medis bagian analisa dokumen rekam medis mengatakan bahwasannya Rumah Sakit Umum Imelda Pekerja Indonesia masih menggunakan standar akreditasi KARS (Komisi
Akreditasi Rumah Sakit) yang merupakan lembaga pelaksana akreditasi yang berasal dari dalam negeri dan data yang didapat penulis jumlah dokumen rekam medis pada bulan Mei sebanyak 440 berkas dan ketidaklengkapan dokumen rekam medis terbanyak terdapat pada form identifikasi pasien dengan jumlah persen $69,14 \%$. Maka dari itu penulis tertarik untuk mengangkat judul "Analisis Ketidaklengkapan Dokumen Rekam Medis Menurut Standar Akreditasi di RSU Imelda Pekerja Indonesia Medan 2018".

\section{Permasalahan}

Berdasarkan latar belakang di atas penulis merumuskan pemasalahan sebagai berikut "Bagaimana Analisis Ketidaklengkapan Dokumen Rekam Medis Menurut Standar Akreditasi di RSU Imelda Pekerja Indonesia Medan 2018”.

\section{Tujuan Penelitian}

Untuk menganalisis ketidaklengkapan dokumen rekam medis menurut standar akreditasi rumah sakit MKI 19.1 pada KARS Versi 2012.

\section{METODE}

Jenis penelitian ini menggunakan metode penelitan deskriptif yaitu diarahkan untuk memberikan gejala-gejala, faktafakta, atau kejadian kejadian secara sistem medis dan akurat, mengenai sifat sifat populasi atau daerah tertentu (Saryono, 2013). Populasi dalam penelitian ini adalah dokumen rekam medis pasien pulang pada bulan Mei 2018 sebanyak 81 berkas.

\section{HASIL DAN PEMBAHASAN}

Berdasarkan hasil penelitian yang dilakukan peneliti tentang ketidaklengkapan dokumen rekam medis menurut standar akreditasi rumah sakit di Rumah Sakit Umum Imelda pekerja Indonesia Medan 2018, data yang diperoleh dari dokumen rekam medis pasien pulang sebanyak 81 berkas. 
Tabel 1. Distribusi Frekuensi Analisis Ketidaklengkapan Dokumen Rekam Medis Menurut Standar Akreditasi Rumah Sakit Kars 2012 MKI 19.1 di Rumah Sakit Umum Imelda Pekerja Indonesia Tahun 2018

\begin{tabular}{lcccccc}
\hline \multirow{2}{*}{$\begin{array}{c}\text { BERKAS REKAM } \\
\text { MEDIS }\end{array}$} & \multicolumn{6}{c}{ KELENGKAPAN } \\
\cline { 2 - 7 } & LENGKAP & TIDAK LENGKAP & TOTAL \\
\cline { 2 - 7 } & F & $\boldsymbol{\%}$ & F & \% & F & $\%$ \\
\hline Identitas pasien & 25 & 30,86 & 56 & 69,14 & 81 & 100 \\
\hline Dokumen pemeriksaan & 27 & 66,67 & 54 & 33,33 & 81 & 100 \\
\hline Diagnosa pendukung & 26 & 32,10 & 55 & 67,90 & 81 & 100 \\
\hline Hasil pengobatan & 43 & 53,08 & 38 & 46,92 & 81 & 100 \\
\hline Justifikasi pengobatan & 30 & 37,04 & 51 & 62,96 & 81 & 100 \\
\hline
\end{tabular}

Berdasarkan tabel di atas dapat dilihat bahwa kelengkapan dokumen rekam medis yang lengkap terbanyak terdapat pada Dokumen Pemeriksaan sebanyak 66,67\% dengan 81 berkas rekam medis pasien pulang, sedangkan ketidaklengkapan terbanyak terdapat pada Identitas Paisen sebanyak 69,14 \% dengan jumlah 81 berkas rekam medis pasien pulang.

Proses Pemantauan Pengisian Lembar Rekam Medis di Rumah Sakit Umum Imelda Pekerja Indonesia (RSU IPI) Medan Tahun 2018

Pemantauan pengisian berkas rekam medis pasien pulang yang dilakukan oleh petugas rekam medis dan perawat ruang perawatan masih kurang efektif dilakukan karena dalam pemantauan tersebut baik perawat maupun dokter masih sering lupa untuk mengisi berkas rekam medis secara lengkap seperti halnya dalam pengisian formuliri dentifikasi pasien karena banyaknya pasien yang dirawat dan kesibukan dokter serta perawat dalam menangani pasien.

\section{Analisis Ketidaklengkapan Dokumen Rekam Medis Menurut Standar Akreditasi Rumah Sakit di Rumah Sakit Umum Imelda Pekerja Indonesia (RSU IPI) Medan Tahun 2018}

Setiap berkas rekam medis yang kembali dari ruang perawatan wajib diperiksa kelengkapannya oleh petugas monitoring dan assembling sebelum berkas diserahkan kepetugas pelaporan.Berkas rekam medis dikembalikan kebagian rekam medis dalam kurun waktu 2x24 jam sejak pasien pulang. Apabila saat dilakukan pemeriksaan kelengkapan ditemukan berkas rekam medis yang tidaklengkap, petugas wajib mengembalikan rekam medis pasien keruang perawatan untuk dilengkapi oleh dokter dan perawat yang memberikan pelayanan kesehatan.

Berkas rekam medis yang kembali dari ruang perawat tidak langsung diperiksa kelengkapannya dikarenakan petugas monitoring dan assembling hanya satu orang jadi perawat yang bertugas diruang rawat diminta untuk melengkapi terlebih dahulu berkas rekam medis.

Identitas pasien merupakan tulang punggung dari efektifitas dan efesiensi sistem rekam medis. Identitas yang benar dibutuhkan untuk memastikan bahwa pasien tersebut hanya mempunyai satu nomor rekam medis. Tanggungjawab atas kelengkapan identitas pasien terdapat pada petugas yang mewawancari pasien ditempat penerimaan pasien atau pada bagian Admission.

Berdasarkan data dari dokumen rekam medis merupakan salah satu elemen penilaian dari standar MKI 19.1 yang berisi tentang rekam medis memuat informasi yang memadai untuk mengidentifkasi pasien, mendukung diagnosa, justifikasi pengobatan dokumen pelayanan diantara tenaga penyedia pelayanan kesehatan. Dokumen rekam medis harus di lengkapi dalam pengisiannya karena di dalam dokumen rekam medis memuat segala aspek aspek dan tindakan yang dilakukan terhadap pasien. Petugas rekam medis di 
RSU Imelda Pekerja Indonesia pada bagian assembling sudah memeriksa dan mengevaluasi ulang setiap kali dokumen rekam medis kembali keruangan rekam medis tetapi masih banyak ketidaklengkapan dokumen rekam medis yang belum lengkap dengan persentase $69,14 \%$ pada fomulir identifikasi pasien.

\section{KESIMPULAN}

Berdasarkan hasil dan pembahasan penelitian yang berjudul "Analisis Ketidaklengkapan Dokumen Rekam Medis Menurut Standar Akreditasi Rumah Sakit di Rumah Sakit Umum Imelda Pekerja Indonesia (RSU IPI) Medan Tahun 2018" maka penulis menyimpulkan bahwasannya ketidaklengkapan dokumen rekam medis yang tidak sesuai dengan standar akreditasi rumah sakit MKI 19.1 pada KARS Versi 2012 dari 81pada berkas rekam medis pasien pulang terdapat pada Identifikasi Pasien dengan jumlah $69,14 \%$.

\section{SARAN}

1. Meningkatkan evaluasi pada bagian assembling untuk melengkapi ketidaklengkapan dokumen rekam medis pada pasien pulang.

2. Memberi sanksi apabila petugas belum lengkap mengisi dokumen rekam medis pasien pulang.

\section{DAFTAR PUSTAKA}

Dirjen Yanmed. (2006). Tentang Pengolahan Data Rekam Medis.

Hatta, Gemala. (2014). Pedoman Manajemen Informasi Kesehatan di Sarana Pelayanan Kesehatan. Jakarta: UI - Press.

Kementrian Kesehatan RI. (2008). Peraturan Mentri Kesehatan RI No.269 Tahun 2008. Tentang Rekam Medis. Jakarta: Kemenkes RI.

Kementrian Kesehatan RI. (2012). Peraturan Mentri Kesehatan RI No.012 Tahun 2012. Tentang Akreditasi Rumah Sakit. Jakarta: Kemenkes RI.

Kementrian Kesehatan RI. (2014). Peraturan Mentri Kesehatan RI No. 56 Tahun 2014. Klasifikasi dan Perizinan Rumah Sakit. Jakarta: Kemenkes RI.

Notoatmodjo. (2012). Metodologi Penelitian Kesehatan. Jakarta: Rineka Cipta.

Rustiyanto, Ery. (2009). Etika Profesi Perekam Medis \& Informasi Kesehatan. Yogyakarta: Graha Ilmu.

Saryon dan Aggreani, Mekar Dewi. (2013). Tentang Metodologi Penelitian Kualitatif Dan Kuantitatif Dalam Bidang Kesehatan. Yogyakata: Nusa Medika.

Undang-Undang Republik Indonesia No. 44 Tahun 2009 Tentang Rumah Sakit. 